\title{
EDITORIAL
}

\section{MEGAESÔFAGO, MEGACÓLON E CÂNCER}

As pesquisas sobre Doenças de Chagas tèm se mostrado de valia para o melhor conhecimento de outros ramos da medicina (patologia, imunologia, fisiopatologia, terapêutica, etc). Talvez seja também possivel se obter, a partir de estudos de chagásicos com megaesôfago (ME) e megacólon (MC), dados que possam ser úteis ao conhecimento da etiopatogênese do câncer do esôfago $(\mathrm{CaE})$ e do cólon $(\mathrm{CaCo})$.

Com relação ao $\mathrm{ME}$ desde o século passado a literatura estrangeira $2 \quad 6 \quad 7 \quad 10 \quad 12 \quad 15 \quad 19 \quad 29 \quad 31 \quad 33$ tem demonstrado significativa associação entre acalasia ou ME e CaE. No Brasil, vários autores 348918202527 2830 têm confirmado os dados dos autores estrangeiros. Poucos são os trabalhos ${ }^{1}$ que contradizem esta associação e os existentes parecem questionáveis.

As razões para explicar a associação ainda não parecem claras. Presume-se que um dos fatores responsáveis pelo desenvolvimento da neoplasia seria o refluxo gastroesofágico por induzir a irritação crônica da mucosa $^{15}$. Seria esta a razão do maior risco de aparecimento de $\mathrm{CaE}$ em portadores de $\mathrm{ME}$ submetidos a condutas terapêuticas inadequadas (miotomia sem cirurgia anti-refluxo, balão repetido, etc.). A estase do bolo alimentar, na porção distal do órgão, também poderia ser outro fator patogenético importante devido à esofagite que desencadeia. A velocidade de proliferação das células da mucosa esofágica tem sido relacionada com a intensidade desta esofagite ${ }^{14}$. Por serem estas células, que resultam de atividade proliferativa maior, mais suscetiveis a transformação maligna haveria, nas condições expostas, maior tendência à formação de neoplasias malignas.

Ainda que pareça bastante provável que o refluxo gastroesofágico seja fator importante na gênese do $\mathrm{CaE}$, visto que fatores irritativos são importantes na etiopatogênese dos tumores em geral, algumas ponderações devem ser feitas. Pela relação causaefeito entre megas e Doença de Chagas, poder-se-ia admitir que a infecção pelo $T$. cruzi fosse a responsável pela associação $\mathrm{MExCaE}$. Trabalho de Lustig et $\mathrm{al}^{17}$, realizado na Argentina, mostra maior freqüência de neoplasias em chagásicos. Estudos por nós realizados no Triângulo Mineiro ${ }^{5}$ não confirmam estes achados. Rocha e cols ${ }^{28}$ mostraram que a relação da neoplasia se dá com a visceromegalia e não com a infecção chagásica. $O$ fato de que a associação $\mathrm{MExCaE}$ ocorra também em casos de $\mathrm{ME}$ não chagásicos, como sucede na Europa e Estados Unidos, parece mostrar que a relação não é com a Doença de Chagas.

\section{MEGAESOPHAGUS, MEGACOLON AND CANCER}

The research on Chagas' disease has brought some improvement to several branches of Medicine (Pathology, Immunology, Physio-pathology, Therapeutics, and so on). The study of chagasic megaesophagus (ME) and megacolon (MC) may also provide for useful data to clarify the etiopatogenesis of the cancers involving those viscera.

Since the nineteenth century the foreign litera-

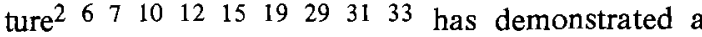
significant association between achalasia or $\mathrm{ME}$ and esophageal cancer (EC). In this country, several authors 3489182025272830 have confirmed those findings. There are very few discordant voices ${ }^{1}$, which are apparently based on questionable oarguments.

The explanation for this association does not seen obvious. As a consequence of the chronic irritation it causes, gastroesophageal reflux is presumably one of the inducers of neoplasia. It is regarded as the explanation for the higher risk of $\mathrm{EC}$ in ME submitted to certain inadequate therapeutic measures (short myotomy without anti-reflux surgery, repeated bougienage pneumatic dilatation, etc.). Due to the esophagitis it causes on the lower third, food stasis might also be another important pathogenic factor. The esophageal mucosal cell proliferative index has been correlated with the degree of esophagitis. The higher proliferative index makes those cells more prone to malignant transformation.

Chronic irritation is a well known factor for the etiopathogenesis of neoplasms. For that matter, in spite of the very likely role of the gastroesophageal reflux for the genesis of $\mathrm{EC}$, a few points should be made. Considering the cause-and-effect relationship linking the megas and Chagas' disease, it would seem fair to accept that the $T$. cruzi infection causes the association ME $x$ EC. In fact, Lustig et al from Argentina ${ }^{17}$ shows a higher incidence of neoplasms in chagasics. However, our studies ${ }^{5}$ do not confirm this finding. In addition, Rocha et $\mathrm{al}^{28}$ showed that the neoplasms correlate with visceromegaly and not with the Chagas' infection. The association of non-chagasic $\mathrm{ME}$ and $\mathrm{EC}$, as found in USA and Europe, seem to show that Chagas' disease it self is not a causative factor for $\mathrm{EC}$.

A few doubts remain on the etiopathogenesis of $\mathrm{EC}$ as related to $\mathrm{ME}$. For instance, if gastroesophageal reflux is an important factor, why does not EC affect preferentially the lower third? This does not seem to happen. On the other hand, EC is reportedly more 
Estabelecido, como parece, que a associação do $\mathrm{CaE}$ é com o mega e não com a infecção tripanossomótica, ainda permanecem dúvidas sobre os mecanismos etiopatogênicos envolvidos na relação $\mathrm{CaExME}$. Assim, por exemplo, se realmente o refluxo gastroesofágico é fator importante não seria de se esperar que os casos de $\mathrm{CaE}$ tivessem como sede preferencial o terço distal do órgão? Isto parece não ocorrer. Outra questão: realmente é a referida associação mais freqüente em pacientes com ME submetidos a terapêutica com balão repetido ou a miotomia sem cirurgia anti-refluxo?

Contrariamente ao observado na relação CaExME, os estudos de MC sugerem não haver associação de câncer de intestino grosso com esta visceromegalia. Isto, aparentemente, parece fácil de explicar, baseado não ser possivel extrapolar o que ocorre na relação CaExME para a associação $\mathrm{CaCoxMC}$. Sendo esôfago e intestino grosso órgãos diversos, com revestimentos epiteliais diferentes, a resposta frente à irritação, que ocorre tanto no $\mathrm{ME}$ como no MC, poderia não ser a mesma. Entretanto uma análise mais profunda do assunto mostra que a questão não parece tão simples. Os portadores de MC apresentam como principal sintoma a prisão de ventre $^{2224}$, com periodos de obstipação que variam de poucos dias a cinco meses 2125 . Por outro lado, sabe-se que na epidemiologia do $\mathrm{CaCo}$ é importante a duração do contato dos carcinógenos presentes no bolo fecal com o revestimento intestinal ${ }^{32}$. Portanto haveria nos pacientes com MC condições predisponentes ao aparecimento do $\mathrm{CaCo}$. Recentemente realizamos estudo sistematizado ${ }^{16}$ sobre o assunto em material de necrópsias e em peças cirúrgicas, concluindo não haver maior prevalência de câncer de intestino grosso em chagásicos com MC. Através de inquérito que realizamos com vários pesquisadores só conseguimos tomar conhecimento de dois casos de câncer de intestino grosso em portadores de MC. Um em Goiânia ${ }^{26}$ e neste caso a neoplasia era de cólon direito, e outro em Botucatu ${ }^{13}$ com câncer de cólon esquerdo. Nos dois pacientes havia adenomaviloso e polipose intestinal, condições sabidamente pré-neoplásicas.

Por que razão ocorrendo, como já se expôs anteriormente, contato mais duradouro do bolo fecal e, conseqüentemente dos carcinógenos nele contidos, com a mucosa intestinal, não haveria maior prevalência de $\mathrm{CaCo}$ em portadores de $\mathrm{MC}$ ? Uma hipótese é que fatores dietéticos (lípides, protideos, fibras vegetais, etc.) e flora anaeróbica ${ }^{112332}$, aos quais se dá hoje grande importância na etiologia do câncer do intestino grosso, poderiam bloquear a ação dos carcinógenos fecais, como parece ocorrer em individuos sem megas. Nada sabemos sobre o comportamento destes frequent with $\mathrm{ME}$ treated with bougienage pneumatic dilatation or short myotomy without anti-reflux surgery?

As opposed to what is found with $\mathrm{EC} \times \mathrm{ME}$, it has been suggested that there is no association of colonic cancer (CC) with megacolon (MC). A ready explanation would be that the esophageal findings cannot be transported to the colon.

The esophagus and colon are dissimilar from each other, with distinct kinds of epithelia. Their responses to the $\mathrm{ME}$ and $\mathrm{MC}$ irritations are not expected to be the same.

However, a closer analysis shows that the problem is not so simple. The major MC symptom is constipation 2224 , for a few days up to 5 months ${ }^{21} 25$. It is also well known that for the epidemiology of CC the length of contact of carcinogens in the stools with the gut epithelium is important ${ }^{32}$. One would then expect that the $\mathrm{MC}$ would be the ideal predisposing condition for CC. Our recent study ${ }^{16}$ with autopsies and surgical specimens has shown that there is no higher prevalence of large bowel cancer in chagasics with MC. The only two cases of megacolon with large bowel cancer we know of are anecdotal ${ }^{4}$, one, right colonic, from Goiania, GO, Brazil ${ }^{26}$, and another, left colonic, from Botucatu, SP, Brazil ${ }^{13}$. Villous adenomas and intestinal polyposis, well known preneoplastic conditions, were found in those patients.

Why would not the longer stool (and its possible carcinogens) contact with intestinal mucosa cause higher prevalence of $\mathrm{CC}$ ? One explanation is that dietary factors (fats, proteins, vegetal fibers, etc.) and anaerobic micro-organisms ${ }^{11} 2332$ might block the fecal carcinogens, as it seems to occur with some individuals without megas. We know nothing on how these factors act on chagasics with MC. Are the chagasics with MC protected against $\mathrm{CC}$ ?

We expect that some light shed on these questions will help EC and $\mathrm{CC}$ to become better understood. 
Editorial. Lopes ER. Megaesôfago, megacólon e câncer. Revista da Sociedade Brasileira de Medicina Tropical 21:91-94, Jul-Set, 1988

fatores nos chagásicos com MC. Haveria menor prevalência de neoplasias de intestino grosso nos pacientes portadores de MC?
O esclarecimento das questões levantadas e de outras mais poderá trazer subsídios para o melhor conhecimento do câncer do cólon e do esôfago.

Edison Reis Lopes

Departamento de Patologia, Medicina Legal

e Deontologia Médica

Faculdade de Medicina do Triângulo Mineiro

Uberaba, Minas Gerais, Brasil 


\section{REFERÊNCIAS BIBLIOGRÁFICAS}

1. Andrade Sá N, Vaz M de GM, Zicker F, Rezende JM, Rosa $H$. É o megaesôfago chagásico fator de risco para o câncer do esôfago? In: Resumos da $\mathrm{V}$ Reunião de Pesquisa Aplicada em Doença de Chagas. Araxá (MG), p. 102, 1988.

2. Barret NR. Achalasia of cardia: reflections upon a clinical study over 100 cases. British Medical Journal 1:1135-1149, 1964.

3. Brandalise NA, Andreollo NA, Leonardi LS, Callejas Neto F. Carcinoma associado a megaesôfago chagásico. Revista do Colégio Brasileiro de Cirurgiōes 12: 196-199, 1985.

4. Câmara Lopes LH. Carcinoma of the esophagus as a complication of megaesophagus. An analysis of seven cases. American Journal of Digestive Diseases 6:742$756,1961$.

5. Chapadeiro E, Lopes ER, Mesquita PM, Pereira FEL. Ocorrência de neoplasias malignas associadas a Doença de Chagas. O Hospital 66: 791-794, 1964.

6. Ellis FH. The natural history of achalasia of the cardia. Proceedings of the Royal Society of London 53: 663$666,1960$.

7. Fagge $\mathrm{H}$. A case of simple stenosis of the esophagus, followed by epithelioma. Guy's Hospital Reports 17:413-421, 1872 .

8. Ferreira EAB. Esofagectomia sub-total e esofagogastroplastia transmediastinal posterior sem toracotomia no tratamento do megaesôfago. Tese de Livre Docência, Faculdade de Medicina da Universidade de São Paulo, São Paulo, 1975.

9. Ferreira Santos R. Tratamento cirúrgico da aperistalse esofágica (megaesôfago). Análise critica da experiência do Departamento de Cirurgia da Faculdade de Medicina de Ribeirão Preto. Tese, Faculdade de Medicina de Ribeirão Preto, São Paulo, 1963.

10. Guisez J. De la frequence de stenóses spamodiques graves et de la precocité du cancer de l'oesophage. Gazette des Hôpitaux civils et militaires (Paris) 92: 479-485, 1919.

11. Hill MJ, Drasar BS, Aries V, Crowther JS, Hawksworth G, Williams REO. Bacteria and aetiology of cancer of large bowel. Lancet 7688:95-100, 1971.

12. Just Viera JO, Haight C. Achalasia and carcinoma of the esophagus. Surgery, Gynecology and Obstetrics 128:1081-1095, 1969.

13. Lima MA de. Comunicação Pessoal, 1988.

14. Livstone EM, Sheahan DG, Behar J. Studies of esophageal epithelial cell proliferation in patients with reflux esophagitis. Gastroenterology 73:1315-1319, 1977.

15. Livstone EM, Skinner DB. Tumors of the esophagus. In: Berr JE (ed). Bockus Gastroenterology. 4nd edition, W.B. Saunders Co., Philadelphia, p. 814-840, 1985.

16. Lopes ER, Meneses ACO, Lopes MAB, Corrêa-Araujo R, Rocha A, Lopes GP, Fatureto M, Chapadeiro E. Câncer de intestino grosso em chagásicos com megacólon. In: Anais do XXV Congresso da Sociedade
Brasileira de Medicina Tropical, Florianópolis ( $\mathrm{SC}$ ), p. 1989.

17. Lustig ES, Puricelli L, Bal E, Lanseti JC. Association of Chagas disease and cancer. Medicina (Buenos Aires), 40: 43-46, 1980.

18. Pinotti HW, Pollara WM, Gemperli R e Raia AA. O problema do câncer no esôfago. Revista da Associação Médica Brasileira 26:379-381, 1980.

19. Rake G. Epithelioma of the oesophagus in association with achalasia of the cardia. Lancet 2:682-683, 1931.

20. Raia AA. Megaesôfago. In: Zerbini EJ (ed). Clínica Cirúrgica Alípio Corrêa Netto. 3a ed. Sarvier, 4? vol., p. 181-204, 1974.

21. Raia A, Campos OM. Megacólon. Contribuição ao estudo de sua patogenia e tratamento. Revista de Medicina e Cirurgia de São Paulo 15:431-442, 467512, 519-560, 1955.

22. Raia AA, Habr-Gama A. Megacolo. In: Raia AA (ed). Manifestações digestivas da Moléstia de Chagas. 1 a ed. Sarvier, São Paulo, p. 207-216, 1983.

23. Raso P, Brasileiro Filho G. Esôfago. Estômago. Intestino. Peritôneo. Mesentério. Retroperitôneo. In: Lopes ER, Chapadeiro E, Raso P, Tafuri WL (ed). Bogliolo Patologia, 4a edição, Guanabara, Rio de Janeiro, p. 495-546, 1987.

24. Rezende JM. Clinica. Manifestações digestivas. In: Brener Z, Andrade Z. (ed). Trypanosoma cruzi e Doença de Chagas. 1a edição, Guanabara Koogan, Rio de Janeiro, p. 312-361, 1979.

25. Rezende JM. Manifestações digestivas da doença de Chagas. In: Dani R, Castro LP. Gastroenterologia Clínica. 1a edição. Guanabara Koogan, Rio de Janeiro, volume 2, p. 1141-1168, 1981.

26. Rezende JM. Comunicação Pessoal. 1988.

27. Rocha A, Henrique $P$, Borges EG, Oliveira VL, Soares VMG, Moraes AT, Teixeira VPA, Almeida HO. Complicaçōes do megacólon e megaesôfago chagásicos observados em necrópsias. Revista Goiana de Medicina 27:53-62, 1981.

28. Rocha A, Almeida HO, Esper FE, Moraes DM, Santos EP, Teixeira VPA. Associação entre megaesôfago e carcinoma de esôfago. Revista da Sociedade Brasileira de Medicina Tropical 16:94-97, 1983.

29. Santy P, Michaud P, Viaro H. Cancer sur mégaesophage. Lyon Chirurgical 54:354-367, 1958.

30. Zillioto Jr. A, Kunzle JE, Araújo EJ, Ricci Go. Carcinoma espinocelular do esôfago. Experiência em 56 casos. Revista da Associação Médica Brasileira 27:253-256, 1981.

31. Williams JL. Carcinoma of the oesophagus as a complication of achalasia of the cardia. Thorax 11:268-274 1956.

32. Winawer ST, Enker NE, Lightdale CJ. Malignant tumors of the colon and rectum. In: Berck JE (ed). Bockus gastroenterology. 4nd. edition, WB Saunders Co., Philadelphia, p. 2531-2574, 1985.

33. Wychulis AR, Woolam GL, Anderson HA, Ellis Jr. FH. Achalasia and carcinoma of the esophagus. Journal of the American Medical Association 215:1638-1641, 1971. 